\title{
$\mathrm{O}$ ato de testemunhar: violência, gênero e subjetividade*
}

\section{Veena Das*}

\section{Resumo}

O contexto é a Partição da Índia em 1949, que levou à criação do Paquistão, visto a partir da cultura punjabi (o Punjab era a província mais próxima da fronteira com o novo estado) $e$, particularmente, através dos olhos de Asha que, aos 21 anos, em 1941, ficara viúva e passara a viver com a família do falecido marido. As transformações impostas pela Partição alteraram essa situação e levaram Asha às seguintes reflexões. A comida de uma filha nunca é pesada para os pais. Mas quanto viverão nossos pais? Quando até dois pedaços de pão são sentidos como "pesados" por nosso próprio irmão... é melhor manter a honra ... e fazer sua paz... e viver onde se está destinada a viver. A exegese dessas reflexões constitui o núcleo analítico do texto. E, sobre a partição, a autora não se pergunta como os acontecimentos estavam presentes nas consciências como acontecimentos passados, mas como vieram a ser incorporados na estrutura temporal das relações.

Palauras-chave: Partição da Índia, Violência, Gênero, Relações Familiares, Punjab.

\footnotetext{
" The Act of Witnessing: Violence, Gender, and Subjectivity, from Veena Das, Life and Words: Violence and the Descent into the Ordinary. (c) 2007 by the Regents of the University of California. Published by the University of California Press. [Tradução: Plínio Dentzien]. O comitê editorial do cadernos pagu agradece as autorizações da autora e da editora para publicar este capítulo do livro.

** Professora de Antropologia no Krieger-Eisenhower, Johns Hopkins University. veenadas@jhu.edu
}

cadernos pagu (37), julho-dezembro de 2011:9-41. 
$\mathrm{O}$ ato de testemunhar: violência, gênero e subjetividade

The Act of Witnessing:

Violence, Poisonous Knowledge and Subjectivity

\begin{abstract}
The context is the Partition of India in 1949, with the creation of Pakistan, as seen from the point of view of Punjabi culture (the Punjab was the province closer to the frontiers of the new state) and particularly through the eyes of Asha, a widow 21 years old in 1941, who lived with his deceased husband's family. The transformations derived from the Partition give rise to Asha's following reflections. A daughter's food is never heavy on her parents. But how long will one's parents live? When two pieces of bread are experienced as heavy by one's own brother... then it is better to keep one's honor... make one's peace ... and live where one was destined to live. The exegesis of this text is the analytical nucleus of the text. The author is not asking how the events of the Partition were present to consciousness as past events but how they came to be incorporated into the temporal structure of relationships.
\end{abstract}

Key Words: Partition of India, Violence, Gender, Family History, Punjab. 
Muitas contribuições recentes à teoria do sujeito argumentam que a experiência de tornar-se sujeito está ligada à experiência da sujeição de maneiras importantes (cf. Butler, 1997 e Mohanty, 1993). As violações inscritas no corpo feminino (literal e figurativamente) $e$ as formações discursivas em torno dessas violações, como vimos, tornaram visível a imaginação da nação como uma nação masculina. $\mathrm{O}$ que isso fez à subjetividade das mulheres? Precisamos perguntar não só como a violência étnica ou comunal foi perpetrada por atos de violação específicos de gênero, como o estupro, mas também como as mulheres tomaram esses signos nocivos de violação e os re-ocuparam através do trabalho de domesticação, ritualização e re-narração. Argumentei antes que as formações discursivas pelas quais o estado-nação foi inaugurado atribuíam um tipo particular de subjetividade às mulheres enquanto vítimas de estupro e rapto. No entanto, a própria formação, por parte das mulheres, de suas posições de sujeitos, embora atoladas nessas construções, não é completamente determinada por elas. $\mathrm{O}$ capítulo anterior argumentou que as mulheres falavam de suas experiências ancorando seus discursos nos gêneros do luto e da lamentação que já lhes atribuíam um lugar no trabalho cultural do luto, mas elas falavam da violência e da dor tanto dentro desses gêneros como fora deles. Através de complexas transações entre corpo e linguagem, elas foram capazes de dar voz e de mostrar os prejuízos causados a elas e também de dar testemunho do dano causado ao tecido social como um todo - o ataque era à ideia mesma de que grupos diferentes fossem capazes de habitar o mundo conjuntamente.

Neste capítulo, espero explorar o significado de testemunhar a violência - de falar em nome da morte de relações. ${ }^{1} \mathrm{Na}$

\footnotetext{
1 Alguns antropólogos se perguntam se a noção de testemunho pode ser posta como lugar analítico a partir do qual escrever, porque argumentam que o forte substrato cristão desse conceito o torna uma categoria inadequada, quando não suspeita, para o trabalho antropológico. Considero essa posição excessivamente restritiva, como se outras culturas (p. ex., o Islã e o Hinduísmo) não tivessem
} 
O ato de testemunhar: violência, gênero e subjetividade

imaginação literária do ocidente, a figura de Antígona como testemunha fornece uma espécie de mito fundador que explora as condições sob as quais a consciência pode encontrar uma voz no feminino. Hegel, como é sabido, viu um conflito de estruturas nessa estória. Em sua leitura, Creonte se opõe a Antígona como um princípio do direito se opõe a outro - digamos, a oposição entre o direito do estado e o direito da família:

O direito público do estado e o instintivo amor familiar e o dever em relação a um irmão estão em conflito. Antígona, a mulher, está pateticamente possuída pelo interesse da família; Creonte, o homem, pelo bem-estar da comunidade. Polinice, em guerra com sua própria cidade-pai, caíra diante dos portões de Tebas, e Creonte, seu senhor, ameaçara de morte, por meio de uma proclamação pública, quem quer que desse ao inimigo dessa cidade o direito de sepultamento. Antígona, contudo, se recusou a aceitar a ordem, que dizia respeito apenas ao bem público, e levada por sua piedosa devoção ao irmão, realizou, como irmã, o dever sagrado do sepultamento (Hegel, 1920:210).

Enquanto estivermos com Hegel, olhando para o diálogo como constituindo a arena da peça, é difícil encontrar outros significados nessa tragédia senão no conflito desses dois discursos. Em contraste, Lacan nos convida a desviar nosso olhar para o cenário trágico de Antígona (1997:243-57). Qual é a natureza da

noções de testemunho. Antes de tudo, noções de testemunho têm significados ligeiramente diferentes nessas religiões - p. ex., shahadat no Islã e a relação entre sakshi e sakhi nas tradições Bhakti no Hinduísmo. De qualquer maneira um conceito não se torna ilegítimo porque suas origens possam estar situadas num discurso adjacente, seja religião ou ciência, a menos que se possa mostrar a maneira específica em que ele afeta a descrição. De minha parte, as noções de testemunho são aqui apresentadas não para atestar a fé diante do corpo mutilado, mas a criatividade da vida. Isso não quer dizer que outras noções de testemunho como no caso dos campos nazistas não sejam extremamente poderosas (ver, especialmente, Agamben, 1999). Porém, nem todas as formas de violência e lembrança podem ser recontadas através desse modelo. 
zona ocupada por Antígona nesse cenário? Lacan o especifica de maneira variada como o limite, como um acontecimento entre duas mortes, como o ponto no qual a morte se encontra com a vida. A cena da morte de Antígona é apresentada nessa zona particular na qual só certo tipo de verdade pode ser dita.

Lacan rejeita a interpretação de Hegel, segundo a qual Creonte se opõe a Antígona como um princípio do direito se opõe a outro. Em lugar disso, ele é mais simpático à posição de Goethe de que, ao atingir Polinice, Creonte passou do limite. A questão, sente Lacan, não é a de um direito contra outro, mas se o direito de Creonte pode subsumir tudo, inclusive os ritos funerários para os mortos. Para Lacan, nunca foi uma questão de um direito contra o outro, mas de uma ofensa contra algo que não é fácil nomear. Lacan insiste em que a paixão de Antígona não é pelos direitos sagrados dos mortos - não é que ela fale pelos direitos da família contra as disposições da lei. Em vez disso, ele chama atenção para a famosa passagem no discurso de Antígona que provocou muita discussão entre os comentadores. Esse é o discurso que Antígona faz depois que todos os movimentos foram feitos - sua captura, seu desafio, sua condenação, seu lamento. Antígona está diante do túmulo em que deverá ser enterrada viva quando faz esse discurso assim parafraseado por Lacan:

Compreendam isso, eu não teria desafiado a lei da cidade por um marido ou por um filho a quem um túmulo tivesse sido negado porque, afinal, se tivesse perdido marido poderia encontrar outro, e mesmo se tivesse perdido um filho poderia ter feito outro com outro marido. Mas diz respeito a meu irmão, nascido do mesmo pai e da mesma mãe (id.ib.:255).

Parece que há duas questões aqui - a primeira é que Antígona se moveu para o limite em que o eu se divide entre o que pode ser destruído e o que deve perdurar e, a segunda, que seu irmão, embora criminoso pelas leis da cidade, é, para ela, um ser único, singular. Antígona faz esse discurso quando já pode se 
$\mathrm{O}$ ato de testemunhar: violência, gênero e subjetividade

imaginar morta - e, no entanto, enfrenta essa dor terrível para afirmar não seus próprios desejos, mas a insubstituibilidade de seu irmão. Lacan, assumindo a voz de Antígona, diz, "Meu irmão pode ser um criminoso, mas do meu ponto de vista meu irmão é meu irmão, o registro de alguém que foi nomeado deve ser preservado" (id.ib.:278).

Para Lacan, parece que é Antígona falando da zona entre duas mortes que pode dar voz à qualidade única do ser. A verdade cujo nome ela diz vai além do direito do estado, e podese dizer que, ao afirmar a qualidade única do seu irmão criminoso, sua paixão evoque o crime subjacente ao direito da cidade. Essa é uma formulação importante do surgimento da voz - destaca que a voz surge no momento da transgressão. Porém, o que distingue a formulação de Lacan das centenas de trabalhos que aparecem a cada ano sobre desejo, prazer, transgressão e localização da capacidade de agir, é que a afirmação da natureza única do ser contra a letra da lei não está localizada na submissão à imediatez da necessidade ou do desejo. Em lugar disso, a zona entre duas mortes é identificada como a zona a partir da qual a verdade indizível sobre a natureza criminosa do direito pode ser dita. Por que é Antígona quem deve afirmar a natureza única da pessoa que a lei do estado condenou como criminosa e que deseja condenar ao esquecimento eterno?

Para Lacan, a verdade insuportável que Antígona diz é terrível demais para enfrentar. Pois, ao questionar a legitimidade de uma regra que apagaria completamente a natureza única de um ser mesmo na morte, ela mostra a criminalidade da própria ordem social. Essa verdade, diz Lacan, precisa do envelope da beleza para escondê-la e, no entanto, torná-la acessível ao olhar. Embora haja um sentido em que se possa encontrar a suspeita da visão, que muitos autores observaram em Lacan (cf. Jay, 1993 e MacCannell, 1986), a relação entre voz e visão é uma relação complicada na articulação desse conhecimento insuportável.

O tema da mulher que encontra a voz quando ocupa a zona entre duas mortes é um tema importante no imaginário indiano: 
constrói-se a partir da divisão por gênero de fala e silêncio em lamentos de luto, mas também se separa dessa divisão. ${ }^{2}$ Mas a verdade articulada a partir dessa zona raramente está envolta em beleza ou esplendor, como testemunham mesmo as conhecidas figuras femininas da mitologia indiana, como a deusa Kali ou a deusa da varíola, Sitala. Em vez de olhar para esse contraste no nível do imaginário tal como articulado na mitologia e na literatura, quero levar o argumento numa outra direção. O que é dar testemunho da criminalidade da regra social que entrega a natureza única do ser ao eterno esquecimento pela descida à vida cotidiana - não simplesmente para articular a perda através de um gesto dramático de desafio, mas para habitar o mundo, ou habitálo outra vez, num gesto de luto? É nesse contexto que podemos identificar o olho não como o órgão que vê, mas como o órgão que chora. A formação do sujeito como sujeito com gênero é então moldada através de transações complexas entre a violência como momento originário e a violência que se infiltra nas relações correntes e se torna uma espécie de atmosfera que não pode ser expelida para "fora." Neste ponto, quero evocar a ideia de Wittgenstein (1953), segundo a qual, não existe o fora, e a imagem de volta que ele oferece, como pensar de um modo humilde de

2 Em certo sentido, a figura de Antígona fala ao trabalho do luto que discutimos no último capítulo do livro. Para Hegel, a comunidade nasce por sua interferência com a família e, portanto, com as mulheres, pois a posição das mulheres perverte a comunidade - elas são o inimigo interno. Como diz Tina Chanter (1995), a ironia da posição das mulheres em Hegel é que elas tornam possível a integridade da polis, e, no entanto devem continuar definidas em oposição a ela como estranhos que ameaçam sua integridade. Luce Irigaray (1985) fala dessas questões de maneira eloquente: "Seu [das mulheres] dever inerente é assegurar o sepultamento dos mortos, transformando assim um fenômeno natural num ato espiritual. Mais um passo (para a negação) e vemos que é tarefa das mulheres, como guardiãs dos laços de sangue, unir o homem em sua figuração final, além do tumulto da vida contingente e momentos esparsos de estar-ali." Para uma discussão importante dessas questões, ver também Carol Jacobs (1996:890-917). Deve estar claro, a partir do último capítulo, que os rituais de luto na Índia supõem uma divisão muito mais complicada da voz e do trabalho entre homens e mulheres. 
$\mathrm{O}$ ato de testemunhar: violência, gênero e subjetividade

usar as palavras: "O ideal, como o pensamos, é inabalável. Você nunca pode sair para fora dele; deve sempre voltar. Não há fora; fora você não pode respirar". 3 .

Essa imagem de voltar evoca não tanto a ideia de um retorno, mas uma volta para habitar o mesmo espaço, agora marcado como um espaço de destruição, no qual você deve viver outra vez. Daí o sentido do cotidiano em Wittgenstein como o sentido de algo recuperado. Como tornar tal espaço de destruição em seu próprio espaço, não por uma ascensão à transcendência, mas por um descenso ao cotidiano, é o que descreverei através da vida de uma mulher, aqui chamada de Asha. ${ }^{4}$ Se a figura de Antígona oferece um modo em que podemos pensar a voz como criação espetacular, desafiadora, do sujeito pelo ato da fala, a figura de Asha mostra a criação do sujeito com gênero pelo envolvimento com um conhecimento que é igualmente venenoso, mas é tratado pelo trabalho cotidiano de correção. No caso de Asha, como veremos, o momento originário da violência da Partição está implicado nos eventos de sua vida porque ela já era vulnerável, como viúva, num universo de parentesco com etos de casta alta Hindu. Mas ser vulnerável não é o mesmo que ser vítima, $e$ os que se inclinam a supor que as normas ou as expectativas sociais da viuvez se traduzem automaticamente em opressão precisam prestar atenção à distância entre a norma e sua atualização. A ideia de apresentar um "caso" aqui não é tanto oferecer um exemplo de uma regra geral ou uma exceção a ela, mas mostrar como surgem novas normas em experimentos com a vida, na auto-criação espiritual. Como os indivíduos colocam normas para si mesmos, e como elas se relacionam com o modo como as normas sociais são imaginadas?

3 Ver Wittgenstein, 1953, parágrafo 103, e também parágrafo 97, em que ele fala de um uso humilde das palavras como maneira de ser capaz de abalar a idéia de uma linguagem perfeita à espera de construção.

4 Como no caso de outros nomes, esse é um pseudônimo, criado por meu próprio investimento nela. Literalmente, o termo significa "esperança." 


\section{Viuvez e vulnerabilidade}

Asha tinha cinquenta e cinco anos quando a conheci. Casada numa família afluente da casta comercial, tinha vivido com seu marido e os dois irmãos mais velhos dele, ambos casados, no lar ancestral em Lahore. Ela enviuvara aos vinte anos, em 1941, quando seu marido contraíra tifo, morrendo três semanas depois de contrair a doença. Ele era o irmão mais jovem numa família fraternalmente unida. Além disso, ele tinha sido muito próximo de suas duas irmãs mais velhas, casadas, que virtualmente o tinham criado desde que a mãe morrera no parto. Ela disse que o pesar das irmãs dele fora tão sofrido como o dela mesma.

Asha lembrava o período inicial de sua perda como um período em que recebeu enorme afeição e apoio de sua família de destino. Ela continuava a morar com a família do irmão mais velho de seu marido. $\mathrm{O}$ fato de não ter filhos lhe pesava. Dizia que tinha perdido todo interesse na vida - seu coração não se dedicava a nada. ${ }^{5}$ Para reavivar seu interesse pela vida, a irmã mais jovem do marido deu a ela seu próprio filho em "adoção." A criança ficava com a própria mãe, mas supunha-se que, quando adulto, assumiria a responsabilidade por Asha, como sua segunda mãe, por assim dizer. Tais arranjos eram comuns dentro de um grupo de parentesco há trinta anos, pois as mulheres frequentemente tratavam seus filhos como "compartilhados" (Bache te ji sajhe honde hain - literalmente, as crianças pertencem a todos). Não era incomum que várias combinações de relações se desenvolvessem em torno de uma única criança. Era uma forma pela qual a comunidade das mulheres cuidava de um membro que tivesse sofrido uma perda. Seria possível dizer que as mulheres desenvolveram subtextos culturais ancorados nos textos patriarcais dominantes da sociedade que, no entanto, criavam

\footnotetext{
5 A expressão literal em punjabi é man nahin lagda e, dependendo do contexto, pode expressar de tédio a sério desinteresse pela vida.
} 
$\mathrm{O}$ ato de testemunhar: violência, gênero e subjetividade

espaços para novas relações. Nesse caso, por exemplo, seria impossível deixar que a viúva adotasse uma criança fora do grupo de parentesco - marcando uma criança de dentro do grupo de parentesco como especialmente dela, as mulheres esperavam que se desenvolvesse uma relação especial entre elas. No entendimento e construção da natureza humana pelas mulheres, sentia-se que uma mulher experimentava mais agudamente a falta da maternidade - donde as irmãs do marido tentaram preencher o vazio da vida de Asha. Pode-se argumentar que essa construção mesma da "necessidade" feminina leva as mulheres a investir o desejo na maternidade e não, digamos, na sexualidade. Portanto, o eu feminino é construído de acordo com os paradigmas culturais dominantes. Isso é verdade - mas veremos que as representações culturais não são completamente gravadas no eu. Se o contexto social se alterar repentinamente, a própria mulher ou outros no seu mundo social podem evocar uma definição diferente da "necessidade" feminina. Assim, as vidas individuais são definidas pelo contexto, mas são também geradoras de novos contextos. $\mathrm{O}$ período turbulento da Partição tornou-se tal evento para Asha ao abrir a relação entre normas sociais e novas formas de subjetividade. Não é que velhas posições como sujeito tenham sido simplesmente deixadas para trás ou abandonadas - ao contrário, havia novas maneiras pelas quais mesmo sinais de dano podiam ser ocupadas. Nesse sentido, a pergunta de como reapropriar o mundo foi reposta para ela, e ela se moveu entre maneiras diferentes em que podia encontrar os meios de recriar suas relações em face do conhecimento venenoso que se infiltrara nessas relações.

Durante a Partição, a família conjugal de Asha perdeu tudo e teve que fugir de Lahore de mãos vazias. A irmã mais velha do marido morreu durante o tumulto. Nunca ficou claro se ela se matou ou se foi sequestrada. Em todas as narrativas sobre Lahore, que ouvi nessa família, havia um apagamento desse período. Por exemplo, vi fotografias de toda a família em que essa mulher agora morta - aparece em vários contextos felizes. Essas ocasiões 
em geral evocavam narrativas do evento retratado na fotografia, mas nunca se fazia referência a sua presente ausência. Uma pergunta como "O que aconteceu com ela?" recebia uma resposta trivial - "Ela morreu nessa época".

Como expliquei no primeiro capítulo, nos meses imediatamente anteriores e posteriores à Partição, os arranjos residenciais eram muito instáveis, com as pessoas mudando de um lugar para outro em busca de empregos, casas e meios de refazer sua existência. A família de origem de Asha vivia em Amritsar, a cidade mais próxima da fronteira no lado indiano - $e$ assim se tornou a primeira fonte de apoio para sua família conjugal. Num dado momento, ela lembrou, quarenta pessoas estavam abrigadas na casa. Lentamente, em alguns meses, como outros parentes em Simla, Delhi e Ferozpur vieram ajudar, sua família conjugal começou a se dispersar para diferentes lugares. Asha ficou com seu filho "adotivo" com a família de seu pai. Mas, embora com o apoio dos pais, seu irmão e a mulher não queriam assumir o peso adicional. Nunca chegaram a dizer isso abertamente, mas talvez o tenham comunicado através de falas veladas e uma estética de gestos. Como qualquer elocução que ganha significado a partir do contexto (o que não quer dizer que não possa ser geradora de contexto), os fragmentos de sua fala que vou citar estão cheios de palavras não inteiramente formuladas, gestos performativos e todo um repertório de noções culturalmente densas que cercam essas elocuções. Assim, embora eu não queira sugerir uma ideia objetivada do significado ("aqui uma palavra, ali um significado", como dizia Wittgenstein), parece-me que preencher o repertório a que cada fragmento aponta permite construir o significado como um processo no qual as elocuções derivam seu significado do mundo da vida mais do que a partir de noções abstratas de semântica estrutural. Certamente, estou ciente de que as regras da semântica estrutural dão o significado das elocuções como entidades linguísticas, mas continuam a ser elocuções desencarnadas. A introdução do sujeito como autor desse discurso precisa de uma introdução do 
$\mathrm{O}$ ato de testemunhar: violência, gênero e subjetividade

contexto, não apenas do contexto linguístico, mas também do mundo da vida como contexto. No entanto, hesito em introduzir aqui a ideia de intencionalidade, porque como a linguagem nos é dada como parole requer certo esquecimento para a elocução, como sugere Gadamer (1985:73-85). O fato de que Asha não se dedicou a me contar a estória do que aconteceu durante a Partição, mas foi contando aqui e ali, quando surgia a ocasião, certos fragmentos do seu mundo, torna esse esquecimento uma parte importante do que foi dito.

Comentando como podemos escutar as palavras de modo a captar a dinâmica da língua, do tempo e da agência política, tal como operam na vida, Robert Desjarlais (2003:107) diz o seguinte:

Tudo isso está nas próprias palavras. Com frequência, porém, é nas palavras da forma como os ouvintes yolmo as ouviriam. Se as elocuções de Kisang isoladas fossem apresentadas a leitores não yolmo, eles perderiam, penso, grande parte - a entonação de sua voz, o que era implicado pelas palavras, como se relacionavam a outras palavras $e$ situações nas vidas yolmo.

Com essas reflexões, volto-me agora às palavras de Asha quando ela filosofava sobre o que ela considerava a relutância de seus irmãos em lhe dar um lar:

A comida de uma filha nunca pesa para seus pais, mas quanto tempo viverão nossos pais? Quando até mesmo dois pedaços de pão são sentidos como pesados por nosso próprio irmão, então é melhor manter nossa honra - fazer sua paz - e viver onde se foi destinada a viver.

A formulação de Asha - uma elocução indicativa - também constitui sua denúncia da vida. Faço uma exegese, tomando trechos diferentes e preenchendo a densa codificação cultural que, espero, fornecerá contexto para entender sua denúncia. Lembro aqui diversos gêneros performativos na Índia, especialmente na 
dança, em que uma curta frase pode ser estendida, através de gestos faciais e dos olhos, até a duração de uma hora.

Primeiro fragmento

A comida de uma filha nunca é pesada para seus pais. (Beti di roti ma pyo te kadi pari nahin hondi). Asha evoca aqui a ideia cultural de que, embora as normas de parentesco orientem uma filha em direção de seus afins, a família natal tem obrigações residuais para com filhas casadas que se deparam com algum infortúnio. Uma mulher sempre pode pedir apoio a seu pai e mãe em caso de problemas - os pais não consideram essa obrigação como um peso por causa de seu amor pela filha (mas é preciso observar que a ênfase está apenas no apoio para sobreviver; se os pais tentarem oferecer mais a suas filhas, podem criar ressentimento entre seus filhos, que se consideram os herdeiros legítimos). Portanto, o que a filha pede como comida da casa do pai não é experimentado como pesado por eles. Há aqui claramente uma forma de subjetividade atribuída aos pais quando Asha assume a voz da filha para reclamar um direito: no entanto, a ideia mais danosa na vida punjabi é que esse direito só é realizado raramente, fazendo da filha uma exilada permanente. ${ }^{6}$

Segundo fragmento

Mas quanto viverão nossos pais? (Ma-pyo kine din rehenge?) Quando uma filha casada faz uma reivindicação a seus pais porque se depara com infortúnio na casa do marido, ela tende a esquecer que o tempo apaga as relações. Inevitavelmente virá o momento em que os pais não estarão mais lá para lhe dar as boas vindas - o poder terá passado às mãos de seu irmão e da mulher dele. Então os dois pedaços de pão que ela reivindica na

6 O gênero das canções das mulheres, especialmente as que assumem a voz da filha mais nova, articula esse dano e é comum a várias regiões da Índia. Ver Egnor1986 e Ann G. Gold e Gloria G. Raheja, 1994. 
$\mathrm{O}$ ato de testemunhar: violência, gênero e subjetividade

casa paterna se tornarão pesados para o irmão e sua mulher. Uma filha deve sempre ter em mente a natureza efêmera de sua reivindicação à casa paterna. $\mathrm{O}$ conceito do tempo como destruidor de relações é um refrão recorrente na vida punjabi e dá conta do fato de que, no momento em que se está vivendo, o real é imaginado em relação ao eventual. Assim, o sujeito é concebido como um sujeito plural, habitando o momento presente, mas também falando como se já estivesse ocupando um momento diferente no futuro. Isso tem implicações importantes para compreender a profundidade temporal em que o sujeito é constituído e a maneira como a memória traumática ${ }^{7}$ inaugura o tempo de construir a cegueira do presente já a partir de um ponto projetado no futuro.

Terceiro fragmento

Quando até dois pedaços de pão são sentidos como "pesados" por nosso próprio irmão... (Jad do rotiyan wi apne hi pra nun pein lagan...) $\mathrm{Na}$ sociedade punjabi, a relação entre irmãos é reconhecida como eivada de tensões que derivam de seu status de co-herdeiros. Há uma tensão adicional entre o princípio de hierarquia pelo qual o irmão mais velho deve ser tratado como pai, pois herda a obrigação moral de olhar pelos mais novos, e o princípio da igualdade pelo qual todos os irmãos têm direitos iguais à propriedade ancestral e devem ser tratados como iguais. Ao contrário, a relação entre irmão e irmã é valorizada como uma relação sagrada em que a irmã dá proteção espiritual ao irmão. Em troca, ela recebe presentes de honra na casa do irmão. ${ }^{8}$ Uma irmã casada que vem de visita em ocasiões rituais traz presentes para os filhos do irmão, como é apropriado, e recebe presentes

7 Não estou usando esse termo num sentido técnico, mas parte da responsabilidade deste livro é oferecer outras maneiras de olhar a experiência da violação, do dano e do trauma.

8 Comparar com Lynn Bennett (1983) para um argumento semelhante no caso do Rajastão. 
dados livremente e amorosamente da casa do irmão, e é considerada como alguém que traz honra a ambas as familias. Mas uma irmã casada desamparada que foi levada a deixar seu lar afim e procurar um lugar na casa de seu irmão passa a ser objeto de desconfiança, especialmente por parte da mulher do irmão, que suspeita que ela possa usar sua posição de filha amada para usurpar uma parte da propriedade do irmão. Muitas das canções de mulheres captam esse sentido da filha casada como exilada seu desejo de visitar a casa do pai é visto como uma desculpa para demandar uma parte da propriedade do pai. É por isso que os dois pedaços de pão que a irmã consome passam a ser vistos como pesados - eles apontam para uma época quando o sofrimento da irmã não será mais ouvido na casa natal. $O$ enquadramento do futuro nesses termos torna insuportável para Asha imaginar sua transformação de filha e irmã amada num peso para a família. É importante observar que Asha não está se queixando da negligência que já experimentou, mas imaginando para onde sua estória seguirá dentro de um possível encadeamento de tais estórias.

Quarto fragmento

...é melhor manter a honra... (...apni izzat bacha ke rakho...). Asha sabe que, nas novas circunstâncias, sua família afim seria levada a apoiá-la. Mas é melhor manter a honra, diz ela, aceitando as humilhações na casa de destino - isso é considerado a sina da mulher. Em contraste, a casa paterna é imaginada como um lugar onde ela tem direito a receber as honras. Portanto, se ela não antecipar o inevitável azedamento das relações e reivindicar o seu direito, ela perderá a honra. No entanto há mais que uma sugestão de desapontamento no fato de que a estória individual não possa se elevar acima do roteiro culturalmente dado em que a temporalidade da relação irmão-irmã é imaginada.

... e fazer sua paz... (... shanti banaye rakho...). Fazer sua paz aqui não tem o sentido de uma submissão passiva, mas de um 
$\mathrm{O}$ ato de testemunhar: violência, gênero e subjetividade

envolvimento ativo - o fazer constante de pequenas coisas que farão com que a família afim passe a vê-la sob um aspecto que não o de uma viúva que é um peso. Por exemplo, enquanto deve apagar completamente sua sexualidade, Asha deve estar sempre disponível para tarefas de que os outros fogem - amassar papads horas a fio, limpar os traseiros dos pequenos, ralar ou socar temperos. De maneira semelhante, a expressão de afeto deve ser cuidadosamente administrada. Como viúva, o rosto de Asha deve sempre exibir a presença constante do pesar - o repartido do cabelo sem a auspiciosa tintura vermelha, ela me disse, era símbolo de tudo que é da natureza de um vazio no cosmos. A exibição da identidade de gênero da viuvez tem a força de um ritual social compulsório. Mas, se o pesar for exibido de maneira muito ostensiva causa desconforto a todos, como se estivessem traindo um falecido irmão ou tio amado, ao rir ou gozar com alguma coisa. Há aqui uma especial estética dos sentidos. Uma viúva, especialmente uma viúva jovem e sem filhos, compreende sua vulnerabilidade, pois deve incorporar em seu comportamento a crença cultural de que não é afortunada - todos os critérios pelos quais seu status desafortunado é exibido estão presentes em sua apresentação -, mas sua relação com seu corpo não é simplesmente um mapeamento desse exterior em seu eu interiorizado. Ela lembra a todos na família de um irmão muito amado que perderam muito cedo, mas cuja memória não deve ser um obstáculo a outras tarefas para levar a vida adiante. Seu rosto e seu corpo devem constantemente exibir essa estética. Mais uma vez, não estou dizendo que há sentimentos, pensamentos $e$ sensações que são "interiores" e um comportamento que é "exterior". Mas toda a postura do corpo, ao oferecer critérios externos pelos quais os outros possam ler o "interno", é um movimento cultural importante que está mergulhado, neste caso, na gramática da viuvez na sociedade indiana. Inclino-me a dizer que o corpo se torna quase expressivo demais para carregar.

...e viver onde se está destinada a viver (literalmente, onde o destino escreveu, aí você fica). (... jithe kismet which likhya hai 
othe hi raho). Eis aí a evocação da ideia cultural de que o destino da mulher está na casa do marido. Esse tema é constantemente reiterado para as meninas, cuja socialização ressalta seu futuro na casa do marido. Mulheres mais velhas frequentemente exprimem a ideia de que uma menina vai para a casa do marido no palanquim nupcial (doli) - e deve sair como uma defunta carregada nos ombros de quatro homens.

A exegese dessa afirmação deixa claro quanto da voz de Asha foi forjado pelas normas culturais patriarcais da viuvez - mas é preciso lembrar que antes da Partição ela não tinha que considerar essas escolhas. Não que as normas fossem diferentes antes, mas que a composição da família e especialmente as relações próximas que ela tinha com a irmã do marido não dava a essas normas a força que elas vieram a adquirir. Embora viúva, Asha se sentia amada e recebera o apoio familiar que a fazia sentir que tinha um lugar legítimo dentro da família afim.

Com a Partição veio uma enorme decadência na sorte da família. Cada unidade da família previamente unida enfrentava novos problemas que pareciam insuperáveis. Onde viveriam? Onde os filhos iriam à escola? Um dos filhos estava pronto para a escola de medicina. Como seu pai levantaria dinheiro para sua educação? Sob os novos tipos de tensão às quais as famílias estavam sujeitas diariamente, Asha descobriu uma mudança sutil nas atitudes dos outros em relação a ela. ${ }^{9}$ Enquanto anteriormente a morte de seu marido era vista como uma grande infelicidade para ela, agora a morte passava a ser uma fonte de culpa sobre ela. Lentamente ela era empurrada para a posição de bode

9 Chamo atenção para a bela maneira como Desjarlais coloca essas questões ele diz de sua interlocutora, Kisang, que "Quando se trata das várias cenas da morte, é melhor pensar sobre elas não como espelhando diretamente qualquer 'experiência vivida' dela, mas como envolvendo domínios existenciais, girando a partir de palavras ditas e pensamentos privados que ela podia invocar ou habitar de tempos em tempos". Desjarlais, Sensory Biographies, 361. Como veremos adiante na narrativa, Asha também viveu algo nesse sentido, e então pergunto o que sou eu em relação a ela - uma discussão que retomo mais tarde no livro. 
O ato de testemunhar: violência, gênero e subjetividade

expiatório. Às vezes, as mulheres da família afim, isto é, a mulher do irmão de seu marido e a irmã do marido, sugeriam que ela fora incapaz de atrair o marido da beira da morte de volta para a vida. Como disse Asha:

Elas davam a entender que ele tinha ficado desapontado com minha aparência. Ele era um homem tão belo, e eu uma mulher comum. Diziam que talvez ele tivesse perdido o interesse pela vida porque realmente não gostava de mim. Isso me fazia sentir tão culpada e com tantos remorsos que muitas vezes pensei em me matar.

Asha viveu entre sua família natal, a família do irmão do marido $e$ a da irmã do marido, durante os quatro anos seguintes:

Em todos os lugares tentei me fazer útil. Trabalhava da manhã à noite. Era tão afeiçoada às crianças que estava disposta a fazer qualquer coisa por elas. Logo os insultos pioraram. E então o insuportável foi que meu jija [literalmente, o marido da irmã, mas aqui usado para referir-se ao marido da irmã do marido, que era viúvo] começou a se insinuar sexualmente (ched chad) para mim, o que era difícil de resistir. Estava dividida entre as lealdades a meu falecido marido e à sua irmã, a quem tinha muito amado, e os novos tipos de necessidades que pareciam ter se aberto pela possibilidade de um novo relacionamento. Comecei a perceber que eu sempre seria a pessoa disponível para novos experimentos. Ele nunca sugeriu casamento, o que teria gerado um escândalo, dado que eu vivera em sua casa tanto tempo. [A implicação é que haveria mexericos de que eles tinham uma relação sexual antiga, que estava sendo simplesmente formalizada]. Finalmente, escrevi para um amigo muito querido de meu marido que vivia em Poona. Ele sugeriu que eu fosse visitar sua família. Quando fui para Poona, persuadiu-me que eu tinha uma vida longa pela frente e que se não quisesse ser constantemente degradada, deveria casar novamente. 
Havia um homem rico em Poona. A mulher o abandonara. Era muito mais velho do que eu, mas esse amigo arranjou um casamento entre nós. Escrevi então para minha família natal (peke) e para os membros de minha família conjugal (saure) que eu tinha me casado novamente. Houve um completo furor, e eles juraram não me ver nunca mais. Disseram que eu os desgraçara com meu comportamento. $\mathrm{E}$, de fato, eu os desgraçara. Eles tinham me envolvido de tanto amor até que suas próprias vidas foram desorganizadas, e eu tinha respondido enxovalhando seus brancos turbantes (pagdis). ${ }^{10}$ Eles não seriam mais capazes de mostrar a face na comunidade. Mas eu estava desamparada.

$\mathrm{O}$ que então se seguiu foi um período de grande tensão para Asha. Embora estivesse casada e nos dois anos seguintes tivesse tido dois filhos, ela parecia incapaz de esquecer suas conexões com a antiga família conjugal. O novo marido também não se inclinava a cortar seus próprios laços com a primeira mulher, que os visitava vinda de sua aldeia para reiterar os direitos de seus filhos à propriedade e afeição do pai. De fato, um dos filhos veio morar com o pai e parecia considerar-se como herdeiro da propriedade do pai. Minha impressão, depois de muitas conversas informais com Asha em que o assunto surgiu, era de que ela se via mais como uma concubina do próprio marido do que como sua esposa. Por exemplo, quando perguntei como ela se sentia como uma mulher jovem quando a ex-mulher do marido os visitava, ela pareceu um tanto surpresa e disse "Mas ela tinha direito de visitá-lo."

Essa maneira de formar uma nova relação, sem nunca abandonar os velhos laços conjugais pode ser uma expressão do forte compromisso religioso com a relação conjugal que, segundo Gananath Obeyesekere (1984), constitui o núcleo dos valores brâmanes. $\mathrm{O}$ que me impressionou, porém, foi que o primeiro

${ }^{10} \mathrm{O}$ pagdis é o signo da honra - o branco se refere à honra mantida. 
$\mathrm{O}$ ato de testemunhar: violência, gênero e subjetividade

marido não parecia preocupar Asha da mesma maneira que a irmã sobrevivente ou a criança que tinha sido "dada" a ela. Referindo-se a ela sempre como "aquela casa", ela fez todo o possível para restabelecer os laços rompidos com a família de seu primeiro marido. Isso era notável, considerando que essas relações poderiam ter sido facilmente apagadas de sua vida, pois eram a fonte de memórias dolorosas. Embora ela nunca falasse sobre isso, parece-me que não teria sido fácil para ela explicar a qualquer pessoa sua adesão a essa família à luz de seu casamento rejeitado. Durante os primeiros cinco anos de seu segundo casamento, ela continuou a escrever cartas à irmã sobrevivente do primeiro marido. E ouvia dela que não havia possibilidade de uma reaproximação. A outra irmã de seu primeiro marido, como contei, morrera em circunstâncias que nunca ficaram claras. $\mathrm{O}$ interesse sexual demonstrado pelo marido da falecida em relação a Asha talvez o tivesse posto na defensiva em relação a ela. Como resultado, ele era virulento em seus ataques à moralidade dela. Mas a irmã mais nova do marido continuou a tentar uma reaproximação e, finalmente, oito anos depois de seu segundo casamento, ela foi convidada a visitar a família.

Fiquei curiosa sobre porque fora tão importante para ela continuar sua relação com sua antiga família conjugal. Sua própria resposta era que ela sentia uma enorme afeição pela irmã do marido que lhe tinha dado seu próprio filho. Também sentia que, ao ter ido embora, fez com que a criança sentisse que não tinha importância na vida dela, quando o fato era que ela sentia que devia sua vida mesma à criança e à sua mãe. E havia também a profundidade temporal em que ela via suas relações.

Quando me casei [disse ela], a irmã de meu marido era muito jovem e ficou muito ligada a mim. Fazíamos todos os tipos de brincadeiras como sinal de nossa relação especial por exemplo, sempre trocávamos nossas dupattas. Quando sentávamos para comer, comíamos do mesmo prato. Ela me dava um bocado, e eu lhe dava outro. Todos na família costumavam rir disso, mas nós realmente nos divertíamos. 
Ela não articulava sua relação à jovem irmã do marido como uma relação individual, mas tendia a derivá-la de sua relação com o falecido marido. Assim, podemos dizer que as relações entre as mulheres se realizavam à sombra do patriarcado, pois elas só podiam reconhecer seu amor pela mediação de um irmão/marido falecido:

Eu não sei. Tive tão pouco tempo com meu marido. Foi quase como se uma flor que estava para brotar fosse colhida do galho. Mas eu tinha tantos desejos que, em outro momento, e nalgum outro lugar eles acabariam por dar frutos. A única coisa importante é que eu devo manter vivas minhas conexões com essa família. ${ }^{11}$

Somos levadas a perguntar qual foi o significado do segundo casamento para ela? Esse casamento, afinal, deu frutos. Houve duas lindas filhas às quais ela parecia muito afeiçoada. Num raro momento de formulação explícita, ela disse:

Tenho sido muito feliz, tive muita sorte de encontrar alguém tão bom para casar comigo. Ele realmente tem olhado por mim. Tenho consciência de ter lhe dado todo conforto. Fui atraída a esse casamento por causa deste corpo desgraçado - ele tem suas necessidades, tem uma existência sobre a qual não tenho controle. Não digo só minhas necessidades. Não podia evitar que os homens me olhassem com luxúria em seus olhos. Não era eu - era este corpo que os atraía. Se o jija ji não tivesse me provocado (ched chad na karde), eu poderia ter vivido uma vida ascética, apropriada a uma viúva, na casa de meu marido. Mas, depois do que aconteceu entre nós, como poderia enfrentar minha cunhada? Como teria enfrentado meu marido em minha próxima vida? Com ele, é uma relação para a eternidade.

\footnotetext{
${ }^{11}$ Comparar com a analogia similar pela qual o divórcio é representado como uma relação não plenamente realizada e não como uma relação que separa duas pessoas no sistema bengali de parentesco, em Ralph W. Nicholas, 1995.
} 
$\mathrm{O}$ ato de testemunhar: violência, gênero e subjetividade

Com meu atual marido - é como se dois gravetos fossem reunidos num mar tempestuoso - a união de um momento e depois o esquecimento. Quero acertar todas as contas com ele nesta vida - todo dar e receber (lena dena) deve ser completado. Então poderei partir sem tristeza. Afinal, ele tem outra esposa e, aos olhos de deus, é ela - e não eu quem ficará com ele. Eu sou uma pecadora (papin).

A partir dessa declaração, pode parecer que Asha tinha profunda ligação com o marido falecido. Mas em conversas com ela, muitas vezes me pareceu que o marido era um personagem muito nebuloso para ela. Ela observou uma vez que, quando viu velhas fotografias dela com o marido, sentia como se estivesse olhando para estranhos. É também notável que são as memórias da irmã do marido que parecem mais concretas e vitais em sua narrativa, pois foi a irmã do marido que lentamente superou as objeções dos homens ao retorno de Asha a suas vidas.

Eu diria que, para muitas mulheres como Asha, a violência da Partição, mais do que o que aconteceu a elas nos tumultos, e a violação brutal de seus corpos, foi o que elas tiveram que testemunhar - isto é, a possibilidade da traição cifrada em suas relações cotidianas. Pensemos por um momento sobre o que foi tido como a dádiva da vida na visão de Asha e como isso envolvia uma forma de ocultação que ela só perceberia com o desenrolar dos acontecimentos. Quem poderia prever que um fato político de grandes proporções viria a mostrar que o lado oculto das relações de parentesco constituía a possibilidade da traição? Encontrei outros casos de tal traição no meu trabalho de campo - a questão é que a horrenda violência dos tumultos comunais solidifica o pertencimento a um grupo num certo nível, mas também tem o potencial de romper as relações mais íntimas num outro nível. $\mathrm{O}$ contrário disso é que as pessoas são levadas a oferecer apoio além de todas as expectativas normais (p. ex., vizinhos de outras comunidades são abrigados sob risco das próprias vidas) portanto, a experiência heterogênea que se tem desses eventos 
não é apenas de ódio e violação, mas também uma experiência de simpatia que pode mostrar virtudes heróicas, interrompendo as longas correntes de reclamações e respostas da vida cotidiana. Mas o modo como esses momentos de paixão são levados para a vida cotidiana requer uma espécie diferente de estória, e meu incômodo com muitas dessas narrativas de ódio apaixonado ou momentos heróicos é que não sabemos como tais momentos são levados à vida cotidiana.

Contei em outro lugar o caso de Manjit, cuja estória retomo no próximo capítulo. ${ }^{12}$ Algumas de suas memórias da Partição eram de um irmão que deixava um pacote de veneno com ela quando saía todo dia, com a instrução de que ela devia engolir o conteúdo caso massas muçulmanas viessem à casa. Manjit, à época com escassos treze anos, tinha a vaga ideia de que, enquanto ele se envolvia em ações indizíveis com quadrilhas formadas por jovens, esperava que ela morresse para não correr $\mathrm{o}$ risco da desonra. ${ }^{13}$ Essa foi uma experiência tão assustadora como a experiência de esperar ser atacada a cada dia ou a experiência de ser resgatada pelo exército. No caso de Asha, foi quando o protetor de ontem virou o agressor de hoje que os projetos de sua vida tiveram que ser reformulados. Em tudo isso, foi a solidariedade forjada entre as mulheres que a ajudou não só a escapar de uma situação sufocante, mas também a ligar o presente com o passado. Mas ela foi incapaz de reconhecer que foi a comunidade das mulheres que a curou, enquadrando essa própria relação dentro das relações homem-mulher dominantes. Talvez isso sugira que, mesmo quando uma mulher rompeu todos os tabus dominantes, como foi o caso de Asha, ela pode não sentir que transgrediu as normas idealizadas: Asha não sentiu que

\footnotetext{
12 Ver Das, "Composition of the Personal Voice".

${ }^{13}$ Acredito que o que era uma vaga ideia de uma criança provavelmente virou uma certeza quanto ela refletiu e trabalhou sua memória como adulta. No próximo capítulo, discuto como ela incorporou esse conhecimento em sua estória.
} 
$\mathrm{O}$ ato de testemunhar: violência, gênero e subjetividade

se tornara outra pessoa - apenas que entrara em arranjos temporários enquanto suas verdadeiras relações ficavam suspensas por algum tempo.

Parece-me que o modo como Asha conta sua estória nos diz alguma coisa importante sobre a relação entre legislação $e$ transgressão. Não é que há primeiro uma lei e então uma transgressão - primeiro um indivíduo que é inteiramente definido pelas normas e então um que transgride. Ao contrário, ao romper o tabu sobre o novo casamento de uma viúva e censurada por isso, Asha sentiu que tinha preservado a integridade das normas, mas não tinha conseguido segui-las. Isso é testemunhado por suas afirmações que a separam de si mesma -

Eu sou uma pecadora - [mas] Depois do que aconteceu entre nós, como podia encarar minha cunhada? Como podia encarar meu marido em minha próxima vida? Com ele, é uma ligação por toda a eternidade.

$\mathrm{Na}$ apresentação de Lacan da paixão de Antígona, ela falava a partir da experiência do limite em que podia ver sua vida como já vivida. Ao justapor a ele o modo muito menos dramático de falar de Asha, espero ter mostrado que em sua descida ao cotidiano, as mulheres como Asha ocupavam uma zona diferente, descendo ao cotidiano em lugar de ascender a um plano mais elevado. Em ambos os casos, porém, vemos uma mulher como testemunha não só no sentido em que ela está no quadro dos eventos, mas em que ela é marcada por esses eventos. A zona do cotidiano dentro da qual Asha falou tinha que ser recuperada pela reocupação dos signos mesmos de prejuízos que foram marcados para gerar continuidade nesse espaço de devastação.

\section{Com os olhos de uma criança}

Até agora contei os acontecimentos da vida de Asha principalmente em sua voz. Quero mostrar uma vinheta de como 
sua primeira visita (depois de ter casado novamente) foi percebida por seu "filho adotivo" (Suraj), que tinha então cerca de oito anos. $\mathrm{Na}$ época em que falou comigo, Suraj era um adolescente, mas ainda lembrava como todos falavam amargamente sobre ela quando chegaram notícias de seu casamento. Falavam sobre como a tinham coberto de afeição, mas ela os tinha traído. Por exemplo, o irmão de seu primeiro marido dizia, "A estreitamos em nosso coração, pensando que ela era o único signo de nosso falecido irmão, mas ela tinha um propósito diferente" (a expressão matlab kadna em punjabi pode referir-se a um uso manipulativo de outros para propósitos egoístas). Um modo comum de conversas familiares entre os punjabis urbanos é dirigir-se a uma pessoa ausente como se ela estivesse presente. Nesse caso ela estava sujeita a escárnio [taunts] ${ }^{14}$, por exemplo, "Kudos a você, oh, rainha - você realmente preservou nossa honra" (vah no rani - tu badi laj rakhi sadi). O filho adotivo disse que sua própria mãe murmurava para si mesma, às vezes na presença dele, "O que é a vida de uma mulher?".

Suraj encarava com tensão a perspectiva de vê-la, sua "outra" mãe. A conversa na família construíra a imagem dela como uma mulher desavergonhada que tinha traído a família $e$ especialmente um voto especial, abandonando seu filho "especial". Quando ela chegou, parecia bem e claramente tinha muita roupa nova e algumas jóias. Seu corpo não era uma proclamação de sua viuvez - Suraj tinha desejado evitar olhar para ela, como se ela fosse deslumbrante demais. Mas ela não exibia sua nova riqueza; dedicou-se a ajudar nas tarefas domésticas, como costumava fazer. Suraj lembrou uma ocasião particular, porque ele insistia em que fossem todos tomar sorvete. Toda a família estava reunida, e os mais velhos não estavam com muita disposição. Mas, disse ele, queria impor sua vontade queria demonstrar que tinha uma situação especial que deveria

${ }^{14}$ A palavra inglesa "taunt" foi incorporada ao punjabi, especialmente como modo de fazer, p. ex. bada taunt karde si” (eles faziam muito escárnio). 
prevalecer. Concedendo a suas demandas, ela foi se trocar e veio vestindo um sári colorido. Chamou-se uma tonga para levá-los ao mercado, e quando eles - Asha, Suraj e uma prima - iam embarcar, seu tio (o mesmo que a tinha sujeitado a seus avanços sexuais) disse: "Não há necessidade de exibir os encantos estilizados (nakhre) de uma sethani". O termo significa literalmente a esposa de um seth ou comerciante rico, mas é usado entre os punjabis para referir-se a uma mulher preguiçosa, que não faz tarefas domésticas, e só está interessada em vestir-se e exibir sua riqueza. Os olhos de Asha se encheram de lágrimas, e quando se sentaram na tonga ela pôs o braço em torno de Suraj e disse: "Veja, por você eu tenho que escutar essa derrisão" (boliyan Sunni paindiyan hain).

\section{Reflexões}

Em anos recentes, a escrita da história e da antropologia tem recebido forte influência das análises literárias das narrativas. Como observou Byron Good (1994) no contexto das narrativas de doenças, contudo, o narrador de uma estória autobiográfica está contando uma estória que não está terminada; ou, como diz Desjarlais, há um eu narrado e um eu narrador, de modo que há duas temporalidades entretecidas na narrativa. No contexto da Partição, os historiadores frequentemente colecionam narrativas orais tentando responder a pergunta: $O$ que aconteceu? Preferi não formular a pergunta nesses termos. Em lugar disso, ver como a violência da Partição incidiu sobre as relações cotidianas animou meu trabalho. Outro modo de dizer isso é dizer que não estou perguntando como os acontecimentos da Partição estiverem presentes nas consciências como acontecimentos passados, mas como vieram a ser incorporados na estrutura temporal das relações, especialmente tendo em mente o caráter projetivo da existência humana.

No caso de Asha, vimos que ela define as relações de parentesco muito mais pelas ideias de proteção, e em sua estória a 
brutalidade da Partição está no que a violência pôde fazer para alterar as maneiras como os parentes se reconhecessem ou deixassem de se reconhecer entre si. Assim, a memória da Partição não pode ser entendida, na vida de Asha, como uma posse direta do passado. Ela é constantemente mediada pela maneira em que o mundo está sendo habitado no presente. Mesmo quando parece que algumas mulheres tiveram uma sorte relativa porque escaparam à violência física direta, a memória corporal de estar-com-os-outros faz com que o passado cerque o presente como atmosfera. Isso é o que quero dizer pela importância de descobrir meios de falar sobre a experiência de testemunhar: que se nossa maneira de estar-com-os-outros tiver sido brutalmente estragada, então o passado entra no presente, não necessariamente como memória traumática, mas como conhecimento venenoso. Esse conhecimento pode ser enfrentado apenas pelo conhecimento através do sofrimento. Como diz Martha Nussbaum (1986:46):

Há uma espécie de conhecimento que funciona pelo sofrimento, porque o sofrimento é o reconhecimento apropriado do modo como a vida é nesses casos. E, em geral: captar seja um amor ou uma tragédia pelo intelecto não é suficiente para ter um conhecimento humano real. Agamenon sabe todo o tempo que Ifigênia é sua filha, se por isso queremos dizer que ele tem as crenças corretas, pode responder muitas perguntas sobre ela, etc. Mas porque, em suas emoções, sua imaginação e seu comportamento, ele não reconhece o vínculo, desejamos unir-nos ao coro dizendo que seu estado é menos o de conhecimento do que de ilusão. Ele não sabe realmente que ela é sua filha. Está faltando um pedaço da verdadeira compreensão. ${ }^{15}$

${ }^{15}$ Estou ciente de que essa citação pode captar uma sensibilidade mais apropriada a uma manifestação anterior de Nussbaum - mas não posso deixar de dizer que sua sensibilidade para a complexa questão da ética no caso grego é 
$\mathrm{O}$ ato de testemunhar: violência, gênero e subjetividade

Quanto a Asha, ela também era conhecida em seu papel como a viúva de um irmão muito amado - seu corpo fora incorporado tanto ritualmente quanto nas interações cotidianas na família no corpo de seu marido morto. Esse era o único aspecto reconhecido de seu ser. Mas outros subtextos podem ter operado - o amor entre a irmá mais jovem do marido e ela mesma, o reconhecimento de que ela era um ser sexual cuja sexualidade fora forçosamente apagada pela morte do marido e pelas demandas da honra familiar. Parece-me que esses eram os subtextos que passaram a ser articulados por causa da turbulência da novidade nascida durante a Partição.

Uma vez reconhecido seu ser sexual no novo tipo de olhar alguém na posição de irmão substituto revelando-se como amante - ela foi levada a uma escolha. ${ }^{16}$ Quereria ela ter uma relação clandestina e participar da "má fé" na qual Pierre Bourdieu (1990) reconhece que se funda a política do parentesco? Ou aceitaria o opróbrio público ao qual sujeitou a honra familiar por uma nova definição de si mesma, que prometia certa integridade, embora como exilada, aos projetos de vida que tinha feito para si mesma? No processo dessa decisão, o sujeito pode ter ficado radicalmente fragmentado e o eu pode ter virado um fugitivo, mas acredito que o que descrevi é a formação do sujeito, uma agência complexa

primorosa, ainda que, no caso da Índia contemporânea ela não queira dizer o mesmo.

${ }^{16}$ É necessário ressaltar que podemos entender as escolhas morais de Asha apenas se pudermos entrar numa vida, num mundo, em que ela sentia que sua eternidade estava ameaçada? Um comentário de passagem de um leitor que estava intrigado sobre como a presença de um cunhado "luxurioso" podia causar tal dilema para Asha me faz querer revisitar o ponto em que a profundidade temporal em que Asha via suas relações - p. ex., sua convicção de que sua relação com o segundo marido era uma aliança momentânea de interesses, mas que em alguma vida futura sua relação com o primeiro marido com quem tinha se casado com o fogo sagrado como testemunha seria retomada - mostra que as escolhas morais em seu mundo de vida não podem ser entendidas fora desse quadro. Isso não é negar que essa estória também é sobre o modo como o patriarcado estrutura o "interior" na sociedade hindu. 
feita de posições fraturadas e divididas de sujeito. Isso fica evidente não necessariamente no momento da violência, mas nos anos de trabalho paciente em que Asha e a irmã do seu primeiro marido repararam os farrapos das relações. Havia o conhecimento venenoso de que ela fora traída por seu mais velho parente afim, e também por seu próprio irmão, que não pode sustentar o compromisso de longo prazo com a irmã desamparada. O que era igualmente importante para ela era o conhecimento de que ela pode ter traído seu marido morto e a irmã morta dele pela imaginação da infidelidade e feito com que seu filho adotivo "especial" se sentisse abandonado. Não foi qualquer gesto heróico, mas o trabalho paciente de viver com esse novo conhecimento - realmente saber não só com o intelecto, mas pelas paixões - que fez do trabalho das duas mulheres descrito simplesmente como ais ghar nal sambandh bana rahe [deixemos que continue a relação entre essas duas casas] - uma instância exemplar de agência como produto de diferentes posições de sujeito - perpetrador, vítima, testemunha.

Nesse ponto, minha análise do que é para Asha e para a irmã de seu primeiro marido trabalhar para superar esse conhecimento venenoso se encontra com algumas reflexões de Cavell (1987:196-97) no sentido de ser amaldiçoado ou ficar doente pelo fato do próprio conhecimento - isto é, de saber mais que os outros sobre as condições do conhecimento. $\mathrm{O}$ contexto dessa reflexão no texto de Cavell é a incapacidade do pai, em The Winter's Tale, de reconhecer o filho como seu, como causado por ele. A expressão de Shakespeare do conhecimento como infectado, de uma aranha mergulhada numa xícara, tem a ver com todo o tema da desconfiança do cético nas relações, suas demandas por mais $e$ mais provas - e, no entanto, o que pode curar essa condição não é mais conhecimento, mas o reconhecimento de que algumas dúvidas são normais e que a cura da suspeita não pode vir de dentro da própria suspeita. Cavell vê 
O ato de testemunhar: violência, gênero e subjetividade

isso como a questão de aceitar ou rejeitar o conhecimento. ${ }^{17}$ Entretanto, assim como Cavell repetidamente aponta para a condição do sujeito moderno dentro do ceticismo (assinalado pela morte de Deus na filosofia), mostrando que a questão é historicamente situada, parece-me que vir a duvidar das relações que a Partição amplificou tem uma especificidade própria. Isso só poderia ser consertado permitindo a si mesma uma descida ao mundo ordinário, mas como se de luto por ele. A recuperação não estava em empreender uma vingança contra o mundo, mas em habitá-lo num gesto de luto por ele. ${ }^{18}$

A relação entre a formação do sujeito e a experiência da sujeição foi captada por Michael Foucault (1977:30) em sua análise da disciplina do corpo numa metáfora de prisão, "a alma é a prisão do corpo". No contexto da prisão, disse Foucault, a disciplina não é uma disciplina que apenas regula o comportamento do prisioneiro, mas invade seu interior e de fato o

\footnotetext{
${ }^{17}$ Ver especialmente o capítulo 6 e a discussão nas páginas 196-97. A ideia de conhecimento venenoso é encontrada outra vez na fantasia da escrita como venenosa. Ver a análise de Cavell dos contos "The Imp" e "The Black Cat": "Tanto a ficção do escritor prendendo a si mesmo e usando grilhões e ocupando a cela do condenado, quanto a ficção de usar uma vela envenenada para ler são descrições ou fantasias da escrita, modeladas pela escrita diante de nós... O que é fantasiar que as palavras são grilhões e celas, e lê-las e estar alertas para seu significado, ou efeito, é estar envenenado? Estão nos dizendo que escritor e leitor são vítimas um do outro? Ou é a sugestão de que para chegar à verdade algo no leitor e também no escritor deve morrer? A escrita mantém afastado ou convida o anjo da morte?" (Cavell, 1988:23). Isso me parece também uma descrição da experiência etnográfica em que são oferecidas formas de conhecimento que ameaçam o eu da antropóloga e de seu interlocutor. Isso não é machismo antropológico ou simplesmente um exercício de autoridade, mas uma maneira de conhecer o mundo que, como todo conhecimento, carrega seu risco de infecção, contágio, veneno.

${ }^{18}$ Eu diria que as sensibilidades cotidianas são o oposto das fantasias míticas de vingança. O exemplo clássico na Índia é a recusa de Draupadi a mudar suas roupas manchadas de sangue menstrual ou pentear os cabelos até que sua desonra fosse vingada. O trabalho clássico sobre isso tudo é "Draupadi's Hair," de Alf Hiltebeitel (1981:179-214).
} 
produz. Embora a inversão da relação de interioridade $e$ exterioridade, de corpo e alma, produza um choque, Foucault ainda me parece dentro da linguagem dominante de interior $e$ exterior.

Tentando entender as complicadas relações entre o desdobramento de uma violência política originária nas relações correntes de parentesco através da vida de Asha, achei tanto os modelos de poder/resistência quanto as metáforas de prisão ferramentas cruas demais para compreender o delicado trabalho de auto criação. Em lugar disso, descobri que, ao explorar a profundidade temporal em que tais momentos originários são vividos, a vida cotidiana se revela como uma busca e uma investigação, como diz Cavell (id.). Assim, em lugar de metáforas de prisão para captar as relações entre critérios externos e estados internos, podemos pensar neles como se protegendo mutuamente, como mantendo uma relação em que estão próximos entre si, unidos do modo como a lei e a transgressão se unem.

É essa relação de proximidade entre a legislação fixadora de normas e a transgressão que parece ter permitido a Asha ter experimentado a si mesma como quem tem demandas à cultura mesma e às relações que a subjugaram. Claramente, a terrível violência da Partição assinalou a morte do mundo como ela o tinha conhecido. Também forneceu um novo modo como ela pode voltar a habitar o mundo. De algumas perspectivas, sua adesão ao passado pode ser lida através da metáfora da prisão algo de que ela é incapaz de escapar. De outra perspectiva, porém, a profundidade temporal em que ela constrói sua subjetividade mostra como se pode ocupar os signos mesmos do prejuízo e dar a eles um significado não só por atos de narração, mas pelo trabalho de reparar relações e reconhecer aquelas que as normas oficiais condenaram. Vejo isso como uma metáfora apropriada para o ato de testemunhar, que é uma maneira de entender a relação entre violência e subjetividade. 
O ato de testemunhar: violência, gênero e subjetividade

\section{Referências bibliográficas}

BENNETT, Lynn. Dangerous Wives and Sacred Sisters: Social and Symbolic Roles of High-Caste Women in Nepal. New York, Columbia University Press, 1983.

BouRdiEU, Pierre. The Logic of Practice. Stanford, Stanford University Press, 1990.

ButLER, Judith. The Psychic Life of Power: Theories in Subjection. Stanford, Stanford University Press, 1997.

CAVEll, Stanley. In Quest of the Ordinary: Lines of Skepticism and Romanticism. Chicago, University of Chicago Press, 1988.

. Disowning Knowledge in Six Plays of Shakespeare. Cambridge, Cambridge University Press, 1987.

CHANTER, Tina. Ethics of Eros: Irigaray's Re-writing of the Philosophers. Nova York, Routledge, 1995.

DESJARLAIS, Robert. Sensory Biographies: Lives and Deaths among Nepal's Yolmo Buddhists. Berkeley, University of California Press, 2003.

EGNOR, Margaret [now Margaret Trawick]. Internal Iconicity in Paraiyar "Crying Songs." In: BLACKBURN e RAMANUJAN (eds.) Another Harmony: New Essays on the Folklore of India. Oxford and Delhi, Oxford University Press, 1986, pp.294-344.

Foucault, Michel. Discipline and Punish: The Birth of the Prison. Nova York, Pantheon Books, 1977.

GADAMER, Hans-Georg. The Hermeneutics of Suspicion. In: MOHANTY, J.N. (org.) Phenomenology and the Human Sciences. Boston, Martinus Nijhoff, 1985, pp.73-85.

GIORGIO, Agamben. Remnants of Auschwitz: The Witness and the Archive. Nova York, Zone Books, 1999 [trad.: Daniel Heller-Roazen].

GolD, Ann G. e RAHEJA, Gloria G. (orgs.) Listen to the Heron's Words: Reimagining Gender and Kinship in North India. Berkeley, University of California Press, 1994. 
GooD, Byron. Medicine, Rationality and Experience: An Anthropological Perspective. Cambridge, Cambridge University Press, 1994.

HEgEL, George W.F. The Philosophy of Fine Art, vol. 2. Londres, G. Bell \& Sons, 1920 [trad.: F.P.B. Osmaston].

HilteBeITEL, Alf. Draupadi's Hair. In: BIARDEAU, Madeleine. (org.) Autour de La déesse hindoue, Purusartha 5, 1981, pp.179-214.

IRIGARAY, Luce. Speculum of the Other Woman. Ithaca, Cornell University Press, 1985 [trad.: Gillian C. Gill].

JACOBS, Carol. Dusating Antigone. Modern Language Notes, III, $\mathrm{n}^{\circ} 5$, 1996, pp.890-917.

LACAN. The Splendor of Antigone. In: MiLLER, Jacques-Alain. (org.) The Ethics of Psychoanalysis: The Seminars of Jacques Lacan, Livro VII. New York, W.W. Norton, 1997, pp.243-57 [trad.: Russel Grigg].

MACCANNELL, J.F. Figuring Lacan: Criticism and Cultural Unconscious. Londres, Croomhelm, 1986.

Martin, Jay. Downcast Eyes: The Denigration of Vision in TwentiethCentury French Thought. Berkeley, University of California Press, 1993.

MOHANTY. J. The Status of the Subject in Foucault. In: CAPUTO, John e YounG, Mark. (orgs.) Foucault and the Critique of Institutions. University Park, Pennsylvania State University Press, 1993.

NichOLAS, Ralph W. The Effectiveness of the Hindu Sacrement (samaskara): Caste, Marriage, and Divorce in Bengali Culture. In: HARLAN, Lindsey e CourTRIGHT, Paul B. (orgs.) From the Margins of Hindu Marriage: Essays on Gender, Religion, and Culture. New York, Oxford University Press, 1995.

OBEYESEKERE, Gananath. The Cult of the Godess Pattini. Chicago, University of Chicago Press, 1984.

Nussbaum, Martha C. The Fragility of Goodness: Luck and Ethics in Greek Tragedy and Philosophy. Cambridge, Cambridge University Press, 1986.

WitTGensteIn. Philosophical Investigations. Nova York, Macmillan, 1953 [trad.: G.E.M. Enscombe]. 